\title{
The Acquisition of English Grammar Among Malay- English Bilingual Primary School Children
}

\author{
Rabiah Tul Adawiyah Mohamed Salleh ${ }^{a}$ \\ rabiahtuladawiyah@iium.edu.my \\ International Islamic University Malaysia, Malaysia \\ Bruno Di Biase \\ B.DiBiase@westernsydney.edu.au \\ Western Sydney University, Australia \\ Wan Nur Madiha Ramlan \\ madyramlan@iium.edu.my \\ International Islamic University Malaysia, Malaysia
}

\begin{abstract}
Studies to document the English acquisitional trajectory of Malaysian learners are scant and this normative data is imperative for syllabus-designers, policy-makers, teachers as well as linguists to understand the root cause of the students' low proficiency in English. Hence, this article presents the acquisition of English grammar among Malay-English bilingual primary school children. Seven nine-year-old children, who have attended the same primary school which employed the Standard Based Curriculum for Primary Schools (KSSR) syllabus for 2 years (i.e., since they were 7 years old) became the subject of this study. The speech output of the children was elicited from two communicative tasks. Their English grammatical acquisition was then analysed using the Processability Theory (PT) framework. Other than the school environment, the children's home language factor was also examined. The results indicate that other than the home language environmental factor, the children's language aptitude also contributes to their English grammatical acquisition. In terms of PT's developmental stages, it was also found that the children's acquisition of English morphology adheres to the stages predicted by PT. The findings also lend credence to PT's typological applicability across different populations.
\end{abstract}

Keywords: English grammar; Bilingualism; Malaysian Primary School Children; Processability Theory; Home Language Practices

\section{INTRODUCTION}

Malaysia is a postcolonial, multiethnic, and multilingual nation located in Southeast Asia. Bahasa Melayu or the Malay language is the official language of the nation that unifies the diverse population which comprises Malays (67.4\%), Chinese $(24.6 \%)$, Indians $(7.3 \%)$ and numerous smaller minority communities, which include various indigenous groups $(0.7 \%)$ (Department of Statistics Malaysia, 2017). Due to this, multilingualism is alive and well in Malaysia with the Malay language, as the National language, being spoken by almost all Malaysians, and other ethnic languages such as Hokkien, Cantonese, Hakka, Mandarin, Tamil, Malayalam, Telugu and many others are actively used by each ethnic community (Mohd Don, 2014). English in Malaysia, on the other hand, is regarded as a second 'strong' language, which is manifested in its institutionalisation as an important Second Language in the Education Ordinance since the nation's independence in 1957 (Azman, 2016). Its status is further

${ }^{a}$ Main \& corresponding author 
reaffirmed with the new education blueprint which places the English proficiency of every Malaysian child as one of its main priorities (Ministry of Education, 2013). It could be said with certainty that for most Malaysians, English has naturally become their second language (L2). Furthermore, as a developing nation, English language proficiency is highly regarded as a desirable attribute for economic and social mobility at the international level. Hence, English language education has been the object of several educational reforms proposed by the government from pre-independence days (Doshi, 2012; Gill, 2005, 2014; Mohd Don, 2014).

Yet, despite the many reforms, the English proficiency and communicative skills of Malaysian students' are reported as being generally below expectations considering that they have been learning English from kindergarten up till the tertiary level, i.e., for at least 11 consecutive years, (Che Musa, Khoo, \& Azman, 2012; Pandian, 2002; Sulaiman, Mohd. Ayub, $\&$ Sulaiman, 2015). Given this concern, many studies have been undertaken to find out why such a phenomenon occurs.

Upon further analysis of the English language studies in the Malaysian setting, it appears that the bulk of the research has focused on examining the proficiency of English among Malaysian tertiary learners and graduates (e.g., Isai, Govindasamy, Ramalingam, Ching, \& Kausalya, 2020; Mohd Zin, Eng, \& Rafik-Galea, 2014; Sarudin, Mohd Noor, Zubairi, Tunku Ahmad, \& Nordin, 2013; Ting, Marzuki, Chuah, Misieng, \& Jerome, 2017; Turiman, Abdullah, \& Mohd Noor, 2018; Zainuddin, Pillai, Francisco, \& Phillip, 2019). This rather narrow scope may be due, at least in part, to the pressure exerted by industrial sectors on institutions of higher learning to produce knowledgeable and skill-based human resources.

We surmise, however, that the scope of research needs to be widened if we wish to understand the underlying cause of Malaysian learners' low English performance. Studies investigating learners' development at the school level are necessary because English in Malaysia is generally acquired through formal instruction, that is through school experience (Azman, 2009). However, it is not known what the level of English that Malaysian children begin with at the outset of their education is. More studies are needed to help educators and policymakers understand the proficiency of students. We need empirical evidence of the students' performance which is contextualised to the Malaysian experience.

Language development, then, should be traced back to the onset of acquisition - which is usually at the early primary school level. Some recent studies have looked at the lexical learning of English amongst Malaysian primary learners, such as those by Lee, Pandian, Rethinasamy, and Tan (2019), Lee, Krishnamoorthy, and Rong (2019), and Meganathan, Thai, Paramasivam, and Jalaluddin (2019). Vocabulary is, without a doubt, the foundation of early language learning. Wilkins (1972) stated that "without grammar very little can be conveyed, without vocabulary nothing can be conveyed" (p.110). This is because it is the lexicon that drives the construction of grammar, as envisaged in lexicalist models of grammar such as Bresnan (2001) and Kaplan and Bresnan (1982), as it is in commonly accepted models of speech production such as Levelt's (1989). Also, several empirical studies have shown that the size of children's vocabulary and their grammatical proficiency are strongly correlated (e.g., Marchman \& Bates, 1994; Moyle et al., 2007; Sansavini et al., 2006).

Yet, analysing vocabulary per se might be insufficient to accurately portray young learners' overall language development. It is essential that their grammatical development is taken into consideration as well. In the Malaysian context, we found that there is a paucity of studies examining the grammatical acquisition of young ESL learners.

Given these premises, this paper aims to investigate English grammatical acquisition among Malaysian primary school children guided by the following research question:

What grammatical forms of English do Malaysian children acquire in early primary school? 
The remainder of the paper is organised, after this introductory remark, into three main sections as follows. The next section reviews a range of related studies in the Malaysian educational contexts, home language practice, language aptitude and briefly presents the theoretical framework adopted for the current research. The second section outlines the methodology that was used to conduct the research including a description of the participants, the tasks and procedures used for data elicitation and the analytical procedures applied to the data. Next, the results and discussion section presents the empirical results and the findings are discussed in light of our theoretical framework for interpreting the children's development in their second language. The paper concludes with the limitation of the study as well as suggestions for future research.

\section{ENGLISH LANGUAGE EDUCATION AND RESEARCH ON MALAYSIAN PRIMARY SCHOOL}

In Malaysia, policies on language-in-education from preschool up till the pre-university level is governed and regulated by the Ministry of Education (henceforth MOE). At the primary level, public schools consist of national schools, in which Bahasa Melayu 'Malay Language' is used as the medium of instruction, and national-type schools (vernacular schools), in which Mandarin or Tamil is used as the medium of instruction. Primary education begins when children reach the age of 7 (Year 1) and continues up until age 12 (Year 6). English is taught as one of the compulsory subjects in both national and national-type schools.

In terms of the broad educational policy environment, the Malaysian government has recently taken the initiative to reform the English language learning in school through what is termed as "The Roadmap 2015-2025" (Ministry of Education, 2015). The roadmap is a guide for English language curriculum designers and educators to ensure that Malaysian students will be able to reach international standards of English communication, as benchmarked against the Common European Framework of Reference (CEFR). In the Roadmap, a total of 285 hours is allocated for the teaching of English at national schools from Year 1 to Year 3 and the guide foresees that by the end of Year 3, students should reach the CEFR level A1. However, it is important to remember that CEFR is based on European contexts and is designed for learners who may be exposed to English outside formal learning hours. In the Malaysian setting, especially for young learners, English is learned in addition to Bahasa Melayu and possibly other ethnic languages, and there is hardly any research to indicate whether the A1 CEFR target might be a realistic benchmark in this context.

CEFR turns out to be, however, a popular framework adopted particularly for testing purposes in the teaching of English in Asian countries such as South Korea, Japan, Taiwan and China (Mohamad Uri \& Abd Aziz, 2018) though several scholars and educators have pointed out some of CEFR's major drawbacks. Wisniewski (2017), for instance, notes that CEFR scales and predictors were never matched onto empirical learner language. Hence, it is unclear whether the scales correspond to authentic learner behaviour or whether they are simply derived from teachers' perspective of learners' development or some official desiderata. More to the point, CEFR does not focus on specific vocabulary and grammatical stages/milestones of learners' development. Its predictors are generic and may not help educators to effectively assess the English acquisition of their students, especially in ESL/EFL context.

To come back to "The Roadmap", we find that the initiatives outlined focus on developing English curriculum and teaching materials, expediting teacher trainings, enhancing assessments as well as improving the administrative framework for adopting the CEFR. Critically, in our view, the English language performance of the students is not given adequate attention and is simply packed together under "Teaching and Learning" (Ministry of Education, 2015, p.173). 
With regard to studies on Malaysian primary learners, the focus, as mentioned earlier, has been on ESL vocabulary acquisition. Educational policies involving English at the primary level have also attracted much attention among Malaysian scholars (e.g., Ali, Hamid, \& Moni, 2011; Azman, 2016; Sabbah, Masood, \& Iranmanesh, 2013; Sulaiman et al., 2015; Yamat, Fisher, \& Rich, 2014; Yamat, Umar, \& Mahmood, 2014). These studies are no doubt, important in highlighting Malaysian educational landscapes. However, the empirical documentation of the pupils' English proficiency, especially in terms of their grammatical development, is critically deficient.

Studies which focus on the acquisition of English among Malaysian children are limited. Much of the literature on English language acquisition in the Malaysian context mostly involve single case studies (Razak, 2014). There are studies by Mohamed Salleh, Kawaguchi, and Di Biase (2019), Mohamed Salleh (2017) and Mohamed Salleh, Kawaguchi, Jones and Di Biase (2016) that investigated the development of English in a Malay-English bilingual child; but the study, however detailed, was conducted on a single child's language development and outside the Malaysian educational environment. There are also case studies by Yusoff, Salehuddin, Abdullah and Toran $(2018,2019)$ who investigated the development of English among Malaysian primary school children with high-functioning autism. Thus, there is a crucial need to establish milestones that will indicate when Malaysian children acquire certain English morphological structures, lexical items and syntax as well as semantic and pragmatic features in Malaysian local contexts (Razak, 2011, 2014). To our knowledge, studies on the acquisition of English among Malaysian children, other than the above-mentioned studies, are scant. Yet information about English milestone development among Malaysian children is crucial in order to offer an evidence-based foundation for educators, syllabus designers, researchers, and speech-language pathologists. Thus, this study might be able to contribute to bridging this gap by contributing to the documentation of the English lexico-grammatical development of Malaysian primary school children at a certain point in their schooling and offer a realistic reference for policy makers and educators.

\section{HOME LANGUAGE PRACTICE}

In Bilingual First Language Acquisition (BFLA), input is a crucial factor in language development (De Houwer, 2009). Pioneering studies in bilingualism such as those by Ronjat (1913) and Leopold (1939) claimed that the one-parent-one-language input is the most effective method to raise bilingual children. However, there are other types of input contexts in which children grow up to be bilingual speakers (e.g., Qi, 2011 and see Romaine, 1996 for a comprehensive review of the input variety). Input mainly depends on the parents' language practice at home and the dominant environmental language of the community. In Malaysia, it was reported that many parents, especially those in the urban areas, opt to speak English at home to further boost their children's English proficiency (Hashim, 2014). For these parents, according to Romaine (1996), their input variety is considered as the "Type 5" variety - the strategy in which the parents or one of the parents talk to the child in a language not of his/her L1. In this case, if parents decide to introduce two languages to the child since birth, or at least before age 3;0, the children are considered as simultaneous bilinguals (De Houwer, 2009: McLaughlin, 1978). In other circumstances, children hear only one language for the first few years and later are exposed to another language. In this case, these children are considered as sequential bilinguals. Under Romaine's classification, this practice is considered as the "Type 2" variety - both parents speak their L1 at home and the child is exposed to the L2 outside the home domain. Sequential bilingual children typically speak their L1 at home with their parents and learn their L2 at school (Genesee, Paradis, \& Crago, 2004). 


\section{LANGUAGE APTITUDE}

Other than the input factor, language aptitude is also one of the determining factors that might contribute to the individual differences in language acquisition, particularly for child second language acquisition (Granena, 2013; Paradis, 2007a). Language aptitude is the amalgamation of analytic and memory skills related to acquiring words and morphosyntactic structures (Dörnyei \& Skehan, 2003). Several studies on early second language learners have found that the L2 attainment is highly associated with language aptitude and personality variables (Genesee \& Hamayan, 1980: Ranta, 2002; Sawyer \& Ranta, 2002). Oller \& Eilers (2002), and Paradis (2007b) further state that if sequential bilinguals began learning their L2 at least in kindergarten (at age 4 onwards) and both languages are highly supported in the community and the educational systems, the initial ability differences between simultaneous and sequential bilinguals emerging from the onsets of acquisition might diminish. Since this study involved a group of Malay-English bilingual children (further details in the methodology), we will see whether language aptitude might contribute to the differences in their acquisition of English grammar.

\section{THE DEVELOPMENTAL FRAMEWORK FOR LANGUAGE ACQUISITION}

The developmental framework that was used to analyse the grammatical development of the children in this study is the Processability Theory (PT) (Pienemann, 1998, 2005; Di Biase et al., 2015). PT is a theoretical framework devised for second language acquisition. It views language acquisition as a hierarchically ordered process whereby learners will follow a certain trajectory in the course of their cumulative development. This path proceeds over a fixed number of stages, each of which is characterised by its own speech processing procedure. Processing procedures are universal and, on that basis, PT has the potential to account for the morphological and syntactic development of any language. The table below schematically shows the universal sequence of processing procedures (leftmost column) applied to the development of English morphosyntax as applied in Di Biase et al., (2015).

TABLE 1. Developmental Stages Hypothesis for L2 English Morphology (Di Biase, Kawaguchi, \& Yamaguchi, 2015; after Pienemann, 1998; 2005)

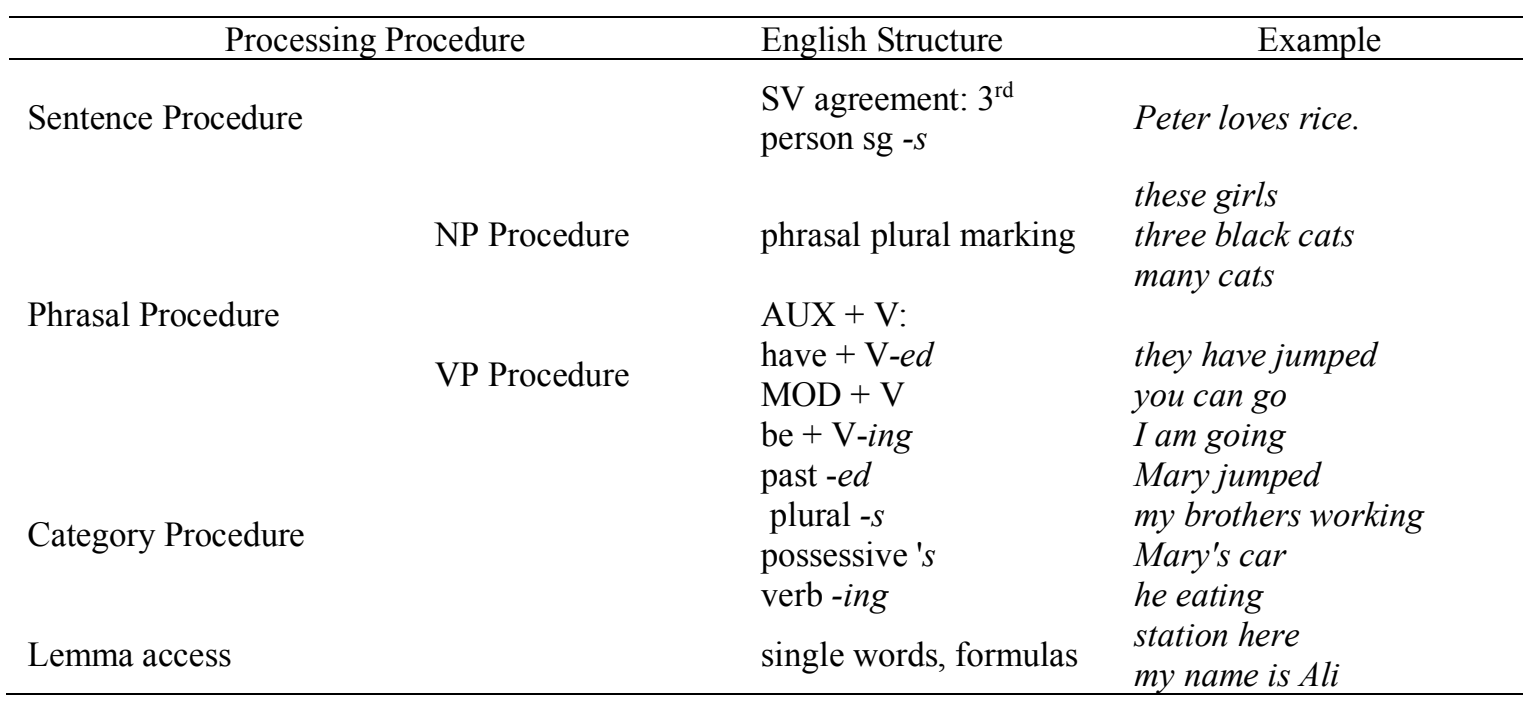

As summarised in Table 1, the first stage in learning a second language is Lemma Access. At this early stage, the learner produces single words and fixed expressions in the new language such as my name is Ali, good morning and other similar items. At this stage, the lexical items 
and expressions are retrieved from the mental lexicon (i.e., learners memorise the words as chunks) and these words are not linked into phrases or sentences because they are not yet annotated for any grammatical features. The second stage is the Category Procedure and it is activated when the learner begins to annotate lexical categories, for example, adding -ing to some words will differentiate them from other words not so marked. Such marking categorises some words as 'verb' and this allows the learner to construct rudimentary 'sentences' such as sister cooking. This typically early marking represents the first stage of grammatical annotation leading eventually to other categorial markings, for example, the $-s$ ending to contrast the [number $=$ plural] value of nouns from their unmarked i.e., [number $=$ singular] value. The next stage in PT is the phrasal stage, where the learner can produce phrases with the correct grammatical agreement, for example, plural agreement as in three cats, many dogs in noun phrases as well as some (limited) pairing up of auxiliaries with (lexical) verbs such as Mary can swim, I am going. The characteristic of this stage is the exchange of information within a phrase, in the sense that a modifier within the phrase must be unified, (i.e., exchange feature/value information) with their phrasal head. The final morphological stage is reached when the learner is able to unify the value of features belonging to different phrases. For example, when they become able to merge information from an initial nominal phrase and the following verb phrase to construct the so-called Subject-Verb agreement in English. For instance, in the sentence Peter loves rice, the form of the verb (loves) must share information about number [singular] and person [ $\left.3^{\text {rd }}\right]$ with the subject (Peter) whose number [singular] and person $\left[3^{\text {rd }}\right]$ values must match those found on the verb. If the features do not match, we would get an ungrammatical construction such as *Peter love rice. The latter kind of constructions would, indeed, be a characteristic in learners at the immediately lower PT stage.

This theory has been widely tested over two decades in many works on second language acquisition across a typologically wide range of languages such as English (Pienemann, 1998; Johnston, 1985; 2000; Yamaguchi, 2013), Arabic (Mansouri, 2005; Mansouri \& Håkansson, 2007), Chinese (Zhang, 2002, 2005; Gao, 2005), Japanese (Di Biase \& Kawaguchi, 2002; Kawaguchi, 2010, 2015), Italian (Di Biase \& Kawaguchi 2002, Di Biase \& Bettoni 2015), Russian (Artoni \& Magnani, 2015), Swedish (Pienemann \& Håkansson, 1999), Spanish (Bonilla, 2014), among others. For children's bilingual language acquisition, PT has been the framework used by Hardini, Di Biase, Kawaguchi, and Reid (2020), Hardini, Kawaguchi, Reid, and Di Biase (2019), Mohamed Salleh (2017), Mohamed Salleh et. al (2016), and Mohamed Salleh et. al. (2019), Medojevic (2014), and Itani-Adams (2013). In all these studies, it was found unanimously that learners, adult, and children alike, follow the stages predicted by PT. Compared to CEFR, PT is very specific in terms of defining learners' grammatical milestones. Given this specificity as well as the widely tried and tested nature of the framework, the PT framework was used in this study in analysing the children's English grammatical development.

\section{METHODOLOGY}

\section{THE PARTICIPANTS AND THEIR LINGUISTIC BACKGROUNDS}

This paper presents a cross-sectional study in investigating the acquisition of English grammar among seven 9-year-old Malaysian primary school children (two males and five females). Prior to the commencement of the research project, the researchers met the parents of each child and obtained their consent to allow their child to participate in the study. This study is the first stage of an ongoing longitudinal research project concerning the lexical and morphological development of these children. At the time the research was conducted, the children were in Year 3 and they had been attending the same school for two years, which is since they were 
seven years old. The school employs the Malaysian public education syllabus and the English lessons are based on the Roadmap (Ministry of Education, 2015). The children had been exposed to English in varying degrees prior to their primary school enrolment. The following table summarises the children's estimated daily exposure to English and Malay:

TABLE 2. Children's daily exposure to English and Malay

\begin{tabular}{|c|c|c|c|c|c|}
\hline \multicolumn{2}{|c|}{$\begin{array}{l}\text { Child's name } \\
\text { (pseudonym) }\end{array}$} & Gender & $\begin{array}{c}\text { Age of first } \\
\text { exposure to English }\end{array}$ & Home language strategy & $\begin{array}{c}\text { Language used outside } \\
\text { home }\end{array}$ \\
\hline 1. & Nana & Female & $\begin{array}{l}0 \text { year old (since } \\
\text { birth) }\end{array}$ & $\begin{array}{l}\text { English ( } 4-5 \text { hours daily) } \\
\text { Malay (1-2 hours) }\end{array}$ & $\begin{array}{l}\text { Malay (school, } 6 \text { hours, } \\
\text { daily) } \\
\text { English ( } 2 \text { hours daily in the } \\
\text { classroom) }\end{array}$ \\
\hline 2. & Lily & Female & $\begin{array}{l}0 \text { year old (since } \\
\text { birth) }\end{array}$ & $\begin{array}{l}\text { English ( } 4-5 \text { hours daily) } \\
\text { Malay (1-2 hours daily) }\end{array}$ & $\begin{array}{l}\text { Malay (school, } 6 \text { hours, } \\
\text { daily) } \\
\text { English ( } 2 \text { hours daily in the } \\
\text { classroom) }\end{array}$ \\
\hline 3. & Fifi & Female & $\begin{array}{l}0 \text { year old (since } \\
\text { birth) }\end{array}$ & $\begin{array}{l}\text { English ( } 2 \text { hours) } \\
\text { Malay ( } 2 \text { hours daily) }\end{array}$ & $\begin{array}{l}\text { Malay (school, } 6 \text { hours, } \\
\text { daily) } \\
\text { English ( } 2 \text { hours daily in the } \\
\text { classroom) }\end{array}$ \\
\hline 4. & Rina & Female & $\begin{array}{l}0 \text { year old (since } \\
\text { birth) }\end{array}$ & $\begin{array}{l}\text { English ( } 4-5 \text { hours daily) } \\
\text { Malay (1-2 hours daily) }\end{array}$ & $\begin{array}{l}\text { Malay (school, } 6 \text { hours, } \\
\text { daily) } \\
\text { English ( } 2 \text { hours daily in the } \\
\text { classroom) }\end{array}$ \\
\hline 5. & Mimi & Female & $\begin{array}{l}4 \text { years old (since } \\
\text { kindergarten) }\end{array}$ & $\begin{array}{l}\text { Malay (4-5 hours daily) } \\
\text { English (1-2 hours daily) }\end{array}$ & $\begin{array}{l}\text { Malay (school, } 6 \text { hours, } \\
\text { daily) } \\
\text { English ( } 2 \text { hours daily in the } \\
\text { classroom) }\end{array}$ \\
\hline 6. & Adam & Male & $\begin{array}{l}4 \text { years old (since } \\
\text { kindergarten) }\end{array}$ & $\begin{array}{l}\text { Malay ( } 4-5 \text { hours daily) } \\
\text { English (1-2 hours daily) }\end{array}$ & $\begin{array}{l}\text { Malay (school, } 6 \text { hours, } \\
\text { daily) } \\
\text { English ( } 2 \text { hours daily in the } \\
\text { classroom) }\end{array}$ \\
\hline 7. & Alif & Male & $\begin{array}{l}4 \text { years old (since } \\
\text { kindergarten) }\end{array}$ & $\begin{array}{l}\text { Malay (4-5 hours daily) } \\
\text { English (1-2 hours daily) }\end{array}$ & $\begin{array}{l}\text { Malay (school, } 6 \text { hours, } \\
\text { daily) } \\
\text { English ( } 2 \text { hours daily in the } \\
\text { classroom) }\end{array}$ \\
\hline
\end{tabular}

The information in Table 2 was supplied by the children's parents and the class teacher. All of the children go to the same school and are in the same class. Outside the home domain, which is primarily the students' 8-hour school session from Monday to Friday, the children are exposed to the Malay language for 6 hours and to the English language for 2 hours daily. The difference between them lies in their home language practice. The varied English exposure amongst the children at home reflects the simultaneous versus sequential nature of their Malay and English acquisition. For Nana, Lily, Fifi, and Rina, they are addressed in Malay and English since birth at home. Thus, they are categorised as simultaneous bilingual children. As for Mimi, Adam, and Alif, they are considered as sequential bilingual children. In their case, English was introduced to them after the Malay language has become somewhat established, which was after the age of 4;0. Their exposure to English only commenced when they began kindergarten.

At the time of writing, the parents of the simultaneous bilingual children in this study (Nana, Lily, Fifi, and Rina) reported that they are still using English predominantly at home. Exposure to Malay for these children is mainly from school and the media. As for the sequential bilingual children (Mimi, Adam, and Alif), the parents reported that they mainly use the Malay language at home. Exposure to English, on the other hand, is mainly from school and the media. 


\section{TASKS AND DATA COLLECTION}

The participants were audio- and video-recorded at their respective home individually in one elicitation session by the researchers. The participants were informed that the session was an English session, so the researchers and the children were required to communicate in English. In the session, each participant was given two communicative tasks: A) spot the difference task between two pictures (see Figure 1) and B) narrating a wordless storybook (see Figure 2). The spot the difference pictures were obtained from https:/eslactive.com/activities/spot-thedifference/ whereas the wordless storybook was obtained from https://freekidsbooks.org/subject/wordless/. Similar tasks are often used in PT research and child language development (e.g., Medojevic, 2014) in order to elicit certain grammatical structures. For task A, the children were asked to point out the differences between the two pictures. The pictures showed animals in plural (e.g., pigs, chicks, ducks) so the targeted structures were the suffix-s and NP plural. For task B, the 12-page colourful book depicted the story of a baby and her 'toast'. The toast was stolen by a group of peacocks while the baby and her family were having a picnic at the park. There were plenty of actions depicted in the wordless storybook, so the targeted structures were the V+-ing. In task B, the children were given some time to observe each page. After approximately 5 minutes, each child was asked to narrate the story. They could look at the picture while narrating the story. If the child was quiet, the researchers prompted the child by using simple encouragements, such as "uh-huh', "go on", "yes", "OK and?", "Anything else?". The researchers minimised the verbal feedback in order not to interfere with the child's narration. Each child was recorded for 10-15 minutes. Altogether, there were 72 minutes of recordings from the session.

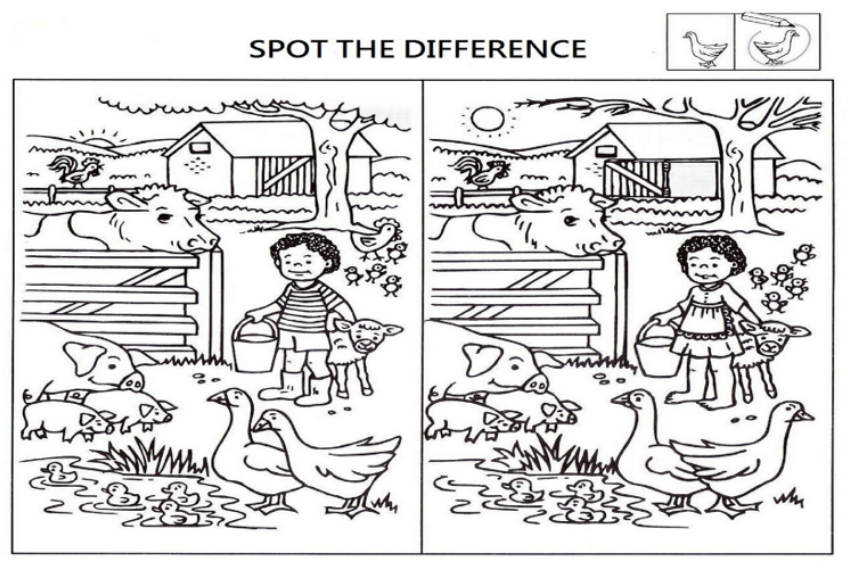

FIGURE 1. Spot the difference task given to the participants

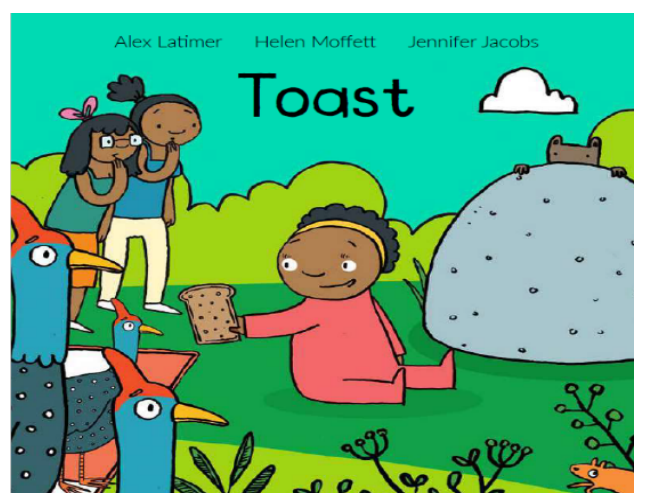

FIGURE 2. Wordless storybook given to the participants for the second task 


\section{ANALYTICAL PROCEDURES}

The recordings were transcribed on ELAN (Sloetjes \& Wittenburg, 2008), a software used to create annotations on video and audio resources. After transcribing, two graduate research assistants rechecked the whole transcription to ensure its reliability. Any discrepancy was then verified from the audio and video recordings. Before analysing the grammar, the size of the lexicon of each child in the recording session was established. The analysis examined the composition of different word categories and the cumulative number of word types in English produced in the session. To this end, the KWIC (Key Word in Context) software was utilised to generate a word concordance for each of the children's speech output. KWIC was used to generate an index of the lexical types indicating the number of occurrences (tokens) for each different word type in the data. For the grammatical analysis, the psycholinguistic framework, the Processability Theory (PT) was used. The systematic and productive production of grammatical structures for each stage of development was analysed using the developmental stages hypothesised in PT.

In determining the acquisition point of each grammatical items outlined in PT, the emergence criteria (Meisel, Clahsen, \& Pienemann, 1981) were used in this study instead of accuracy counts. As Pallotti (2007) points out, emergence is not whether the learner has used the structure or not, rather whether the structure is used systematically and productively. Systematic use is determined from a sufficient number of tokens or contexts (formal variation) and productivity refers to the structure being used with a variety of lexical items (lexical variation). A structure is considered 'emerged' if the production data contains both formal and lexical variation of the same structure. For example, the suffix $-s$ plural is considered emerged if it is instantiated on formal variation (e.g., ball vs balls) and lexical variation (e.g., balls, bananas). So, in this study, once there is evidence for both formal and lexical variations in the participants' output, the grammatical structure is considered to have emerged.

\section{RESULTS AND DISCUSSION}

This section discusses the results obtained from these primary school children after having learned English for 2 years in school. The discussion is guided by the research question posed earlier:

\section{What grammatical forms of English do Malaysian children acquire in early primary school?}

We first look at the children's lexical tokens and types. Table 3 shows the lexical tokens and types produced by the children in response to the elicitation tasks in the recording session:

TABLE 3. Number of lexical tokens and types of each child

\begin{tabular}{lllllllll}
\hline CATEGORY/CHILDREN & NANA & LILY & FIFI & ADAM & MIMI & RINA & ALIF & EXAMPLES \\
\hline NOUNS & 35 & 38 & 37 & 36 & 27 & 25 & 21 & Apples, muffins, duck \\
VERBS & 26 & 24 & 30 & 23 & 19 & 23 & 20 & Take, gave, is running \\
ADJECTIVES & 8 & 13 & 14 & 16 & 7 & 14 & 11 & Green, blue, pretty \\
OTHERS & 85 & 56 & 51 & 54 & 46 & 28 & 38 & Yes, okay, no \\
TOTAL TYPE & 154 & 131 & 132 & 129 & 99 & 90 & 92 & \\
TOTAL TOKEN & 449 & 408 & 360 & 346 & 275 & 224 & 215 & \\
\hline
\end{tabular}

It can be seen from Table 3 that all children produced around the range of 90-154 lexical types. Nouns was the highest lexical form followed by verbs. English is regarded as a "noundominant' language (Gentner \& Boroditsky, 2001), so the preponderance of nouns produced by the children in this study corroborate the 'noun-dominance' nature of the English language. Previous studies on L1 English monolingual children have shown that nouns are the earliest 
and predominant lexical item acquired by children (Fenson et al., 1994). In bilingual acquisition research, studies by Itani-Adams (2013) and Mohamed Salleh (2017) have shown that when speaking in English, the bilingual child tends to exhibit higher use of nouns, which is also observed in our participants. From the data presented in Table 3, we deduced that the children are already beyond the PT lemma stage. As explained previously, at the first stage of PT, the L2 lexicons are not grammatically annotated and learners tend to produce 'chunks' or formulaic expressions. Since the children in this study have produced over 200-400 lexical tokens, with over 90-150 lexical types in the recording session, we can safely say that they are already beyond the one-word/formulaic stage. The morphological development of the children based on PT stages is shown in Table 4. The numbers of occurrences for morphological structures are entered in Table 4 with a plus $(+)$ sign if the structures are supplied in obligatory contexts; with a minus (-) sign if not supplied in obligatory contexts; an empty cell marks no occurrence for a structure.

TABLE 4. The children's morphological development based on PT stages

\begin{tabular}{llccccccc}
\hline STAGE & STRUCTURE & FIFI & ALIF & ADAM & RINA & NANA & LILY & MIMI \\
\hline $\begin{array}{l}\text { S- } \\
\text { PROCEDURE }\end{array}$ & $\mathbf{3}^{\text {rd }}$ pers sg $-\boldsymbol{s}$ & & -7 & -6 & -3 & -2 & +1 & $+2-2$ \\
NP & quantifier + pl - & +8 & $+1-2$ & $+1-3$ & +6 & +8 & +10 & +6 \\
PROCEDURE & $\boldsymbol{s}$ & & & & & & &
\end{tabular}

\begin{tabular}{|c|c|c|c|c|c|c|c|c|}
\hline \multirow[t]{2}{*}{$\begin{array}{l}\text { VP } \\
\text { PROCEDURE }\end{array}$} & $\begin{array}{l}\text { Have+ V-ed } \\
\text { MODAL + V }\end{array}$ & & & & & +1 & & \\
\hline & $\begin{array}{l}\text { MODAL + V } \\
\text { be }+ \text { V-ing }\end{array}$ & +14 & $+1-1$ & +8 & +10 & +10 & +11 & +6 \\
\hline $\begin{array}{l}\text { CATEGORY } \\
\text { PROCEDURE }\end{array}$ & $\begin{array}{l}\text { past -ed } \\
\text { plural -s } \\
\text { possessive 's } \\
\text { V-ing }\end{array}$ & $\begin{array}{c}+1 \\
+8-2 \\
+1 \\
+2\end{array}$ & $\begin{array}{c}+1 \\
+3-1\end{array}$ & $\begin{array}{c}+4-5 \\
-1\end{array}$ & $\begin{array}{l}+4 \\
+2\end{array}$ & $\begin{array}{c}+2 \\
+7-4 \\
+2 \\
+1\end{array}$ & $\begin{array}{l}+2 \\
+5-2 \\
+1-1\end{array}$ & +6 \\
\hline $\begin{array}{l}\text { LEMMA } \\
\text { ACCESS }\end{array}$ & $\begin{array}{l}\text { Word level } \\
\text { (token/type) }\end{array}$ & $360 / 132$ & $215 / 92$ & $346 / 129$ & $224 / 90$ & $449 / 154$ & $408 / 131$ & $275 / 99$ \\
\hline
\end{tabular}

Lemma Access: This is the first stage of PT where the L2 lexicon hardly contains any grammatical diacritics. As stated earlier, the children had already produced more than 200 lexical tokens and more than 90 lexical types in the recording session. Hence, they are already beyond the one-word/formulaic stage.

Category Procedure: The category procedure, as stated by Di Biase et al (2015), is the most 'crowded' stage for English as there are four separate morphological structures predicted to emerge. The structures are not required to emerge simultaneously for learners to be considered to have passed the stage. In many PT-based studies (e.g., Di Biase et al, 2015), it has been found that the earliest grammatical structure to emerge in L2 learners (children as well as adults) is the $V$-ing (e.g., playing, without the auxiliary be). This step is not target-like, but it allows learners to differentiate noun-like lemmas, their earliest emerging lexical category, from verb-like categories. Thus, PT places this step at the categorial procedure. In this study, however, not all children produced $V$-ing, except for Rina, Fifi, and Nana, with only 1-2 occurrences each.

Moving up is the possessive 's marker. In the recordings, we have found that there are limited occurrences of possessive 's marker in the children's output. For example, only Fifi, 
Lily, and Nana produced possessive 's, such as "the cow's eyes", "the skunk's leg", and "Sunny's toast". The other children produced possessive determiners instead (e.g., its, his, her, their) when describing possession throughout the recording session. Interestingly, this finding is consistent with Johnston's early work with adult migrants in 1985 (Johnston, 1985) in which he found a paucity of occurrences for possessive 's in his cross-sectional study.

Another marker in the category procedure stage, which is abundantly produced by the children when compared to other structures within this stage, is the plural suffix $-s$ for nouns. In English, a plural referent is marked through the use of suffix $-s$ (cat vs cats). Additionally, learners must also be aware of the countability feature of the referent, specifically, whether the item is countable (e.g., apples and tomatoes), or not countable (e.g., water, milk, rice). The children in this study were found to produce plenty of suffix $-s$ when pluralising bare nouns (e.g., birds, ducks, muffins).

The last grammatical structure in the Category Procedure stage is the past -ed marker. In Table 4, the production of past tense -ed was also found to be significantly lower than other structures in the category stage. Further analysis of the verb forms produced by the children reveals that instead of the past -ed marker, there are plenty of irregular past verb forms that the children used in the session. These are all high-frequency verbs, which tend to be much more commonly used in children's speech than regular verbs. As shown in Table 5, which indicates the various verb forms produced by the children in the session, the past -ed suffix was only used in a few verbs such as pointed, ended, followed, grabbed, and turned. Irregular verbs, on the other hand, compared to regular verbs that mark past tense with the suffix -ed, was produced more by the children, both as a number of types and as a number of tokens.

TABLE 5. Children's verb forms produced in the recording session

\begin{tabular}{|c|c|c|c|c|c|c|}
\hline $\begin{array}{l}\text { Children } \backslash \text { Verb } \\
\text { form }\end{array}$ & Base form & $\begin{array}{l}\text { Irregular } \\
\text { verb }\end{array}$ & V-ing & Past -ed & be + V-ing & $3^{\text {rd }}$ per. sg $-s$ \\
\hline MIMI & $\begin{array}{l}\text { Take (2) } \\
\text { Run (1) } \\
\text { Find (1) }\end{array}$ & $\begin{array}{l}\text { Came (2) } \\
\text { Saw (2) } \\
\text { Found (2) } \\
\text { Got (1) } \\
\text { Ran (1) }\end{array}$ & & & $\begin{array}{l}\text { Is holding (2) } \\
\text { Is wearing (2) } \\
\text { Were bringing } \\
\text { (1) }\end{array}$ & $\begin{array}{l}\text { Sophia gives } \\
\text { the bread (1) } \\
\text { She gets the } \\
\text { cookie (1) }\end{array}$ \\
\hline LILY & $\begin{array}{l}\text { Live (1) } \\
\text { Follow (1) } \\
\text { See (1) }\end{array}$ & $\begin{array}{l}\text { Saw (2) } \\
\text { Went (2) } \\
\text { Ate (2) } \\
\text { Ran (1) } \\
\text { Thought (2) } \\
\text { Gave (1) }\end{array}$ & Going (1) & $\begin{array}{l}\text { Closed (1) } \\
\text { Followed (1) }\end{array}$ & $\begin{array}{l}\text { Is going (4) } \\
\text { Are going (1) } \\
\text { is looking (3) } \\
\text { were looking } \\
\text { (1) } \\
\text { were having (1) } \\
\text { are telling (1) }\end{array}$ & $\begin{array}{l}\text { The baby } \\
\text { gives the bird } \\
\text { the bread(1) }\end{array}$ \\
\hline NANA & $\begin{array}{l}\text { Close (1) } \\
\text { Get (1) } \\
\text { Give (1) } \\
\text { Go (1) } \\
\text { Make (1) } \\
\text { Open (1) } \\
\text { Use (1) } \\
\text { Walk (1) } \\
\text { Spot (1) }\end{array}$ & $\begin{array}{l}\text { Ran (5) } \\
\text { Stole (4) } \\
\text { Got (1) } \\
\text { Rose (1) } \\
\text { Saw (2) }\end{array}$ & Chasing (1) & $\begin{array}{l}\text { Grabbed (1) } \\
\text { Turned (1) }\end{array}$ & $\begin{array}{l}\text { Is setting (1) } \\
\text { Is wearing (2) } \\
\text { Is turning (2) } \\
\text { Is entering (1) } \\
\text { Are having (1) } \\
\text { Is eating (1) } \\
\text { Are chasing (1) } \\
\text { Was eating (1) }\end{array}$ & \\
\hline FIFI & & $\begin{array}{l}\text { Stole (3) } \\
\text { Came (2) } \\
\text { Kept (2) } \\
\text { Gave (1) } \\
\text { Took (1) } \\
\text { Found (1) }\end{array}$ & Ended (1) & $\begin{array}{l}\text { Is facing (1) } \\
\text { Were taking (2) } \\
\text { Were walking (1) } \\
\text { Were setting (2) } \\
\text { Is holding (1) } \\
\text { Was chasing (2) }\end{array}$ & & \\
\hline
\end{tabular}




\begin{tabular}{|c|c|c|c|c|c|}
\hline & & & & $\begin{array}{l}\text { Kept chasing (1) } \\
\text { Kept running (1) } \\
\text { Is standing (1) }\end{array}$ & \\
\hline \multirow[t]{6}{*}{ ADAM } & Catch (3) & Gave (1) & Fighting & Said (3) & Is catching (2) \\
\hline & Want (3) & Got (1) & (1) & & Is looking (2) \\
\hline & Give (1) & & & & Are looking (1) \\
\hline & Run (1) & & & & Is eating (2) \\
\hline & & & & & Is drowning (1) \\
\hline & & & & & Is taking (1) \\
\hline \multirow[t]{8}{*}{ RINA } & Eat (1) & Fell (2) & Going (1) & Pointed (1) & Are having (1) \\
\hline & Go (1) & Got (2) & Falling (1) & & Are waving (1) \\
\hline & Hold (1) & Saw (1) & & & Start chasing \\
\hline & & Left (1) & & & \\
\hline & & & & & Are looking (1) \\
\hline & & & & & Is chasing (2) \\
\hline & & & & & Is eating (2) \\
\hline & & & & & Are doing (1) \\
\hline \multirow[t]{7}{*}{ ALIF } & Want (5) & Got (1) & Going (1) & Said (2) & Is holding (1) \\
\hline & Give (2) & Lost (1) & & & \\
\hline & Follow (1) & & & & \\
\hline & Run (1) & & & & \\
\hline & Say (1) & & & & \\
\hline & Eat (2) & & & & \\
\hline & Tell (1) & & & & \\
\hline
\end{tabular}

Among the most recurring irregular verbs the participants used are saw, got, went, and gave. Irregular verbs were found to be acquired by rote memory (Bybee, 1995; JacksonMaldonado, 2004; Nicoladis, Song, \& Marentette, 2012b), that is, they are learned by item. According to Nicoladis et. al. (2012a), the regular past tense marking is high in type frequency but not necessarily in token frequency; high token frequency usually leads to memorisation and that might explain why children in this study displayed high use of irregular verbs. In terms of the developmental pattern of past marking tense, the findings have generally shown that the pattern of development is similar for both monolingual and bilingual children (Jia \& Fuse, 2007; Nicoladis \& Paradis, 2012a; Nicoladis et al., 2012b; Paradis, Nicoladis, Crago, \& Genesee, 2010); albeit for bilingual children, their acquisition of the structure was found to be later than monolinguals.

Typically, when learning a new verb, children tend to use the unmarked form of the verb (i.e., the base form), followed by considerable use of irregular verbs. Later, once the past -ed structure has emerged, they tend to overgeneralise the suffix, as reflected in the following examples from previous L1 research, ringed instead of rang and holded instead of held (BerkoGleason, 1958; Marcus et al., 1992). However, we have yet to see this pattern in our data because the children have not learned a sufficient number of -ed verbs to start generalising such pattern. As far as PT is concerned, these past forms are lexically based and need to be learned one by one as with any lexical item. In any case, the past -ed marker was learned quite late in the longitudinal study by Di Biase et al. (2015) as it coincided, temporally, with the child advancing to the interphrasal stage (S-Procedure), even though the structure is placed at the much lower 'lexical' stage.

Phrasal Procedure: The next higher morphological procedure is the Phrasal Procedure stage. The Phrasal Procedure stage is more complex because learners need to activate the phrasal procedure which requires "feature unification" (Pienemann, 1998, 2005). At this stage, learners are required to activate an exchange of information at the phrasal node between the lexical components of the phrase, i.e., the Noun and the quantifier in the Noun Phrase (NP) and the Auxiliary and the Lexical Verb in the Verb Phrase (VP) to produce a complete and coherent 
phrasal structure. This stage is instantiated through either be $+V$-ing (e.g., is playing), have $+V$ ed (e.g., have played), a bare infinitive with Modal (e.g., can play), or between the NP plural and its determiner (e.g., many cats).

Recall that earlier in the Category stage, the occurrences of $V+$ ing (e.g., playing) by the participants are quite low. We postulate that this is not because the participants skipped a stage, rather, the lack of occurrences of $V+$-ing in some of the participants is attributed to the fact that most of them had acquired the VP stage and produced $b e+V$-ing structure (e.g., is chasing, was eating, were running). As evidenced in Table 2 as well as Table 5, there are many occurrences of be+ $V$-ing with different lexical verbs, which means that this grammatical construction is acquired by all children at this point with one possible exception in the case of Alif. Alif produced only one occurrence of $b e+V$-ing structure and when he repeated the sentence, he used the base form instead, "The baby is holding the bread. The baby hold the bread". Such variability and occasional use of a grammatical structure usually occur when a structure has just emerged. In many First Language Acquisition (FLA) and Bilingual First Language Acquisition (BFLA) studies (e.g., Clark \& Nikitina, 2009; Hardini et. al., 2020, 2019; Mohamed Salleh et. al., 2016, 2017, 2019), it was found that when children newly acquire a certain grammatical structure, the use of that structure tends to be in a piecemeal manner and it tends to be interchangeably used with a semantically compatible form (i.e., the base form), which is also easier to process. So, in this context, we consider Alif as very close to reaching the VP stage.

A further look at the VP stage in Table 2 reveals the 'absence' of Have $+V$-ed structure in the children's output, as well as Modal auxiliary + Verb structures of which we find only one instance supplied by Nana (I can make my own names, right?). This is possibly due to the context provided; the materials used in the elicitation of data may provide insufficient contexts for the use of modal verbs. The spot the difference picture and the wordless storybook used contain plenty of more-than-one entities pictures as well as many pictures depicting ongoing actions, hence the children in the study produced many grammatical items related to plurality for nominals and $V$-ing for verbs.

Regarding the NP stage, the children's production of the more complex phrasal plural involving a quantifier + Noun + suffix $-s$ (e.g., many ducks, five chicks), marking plural 'agreement' within the NP was remarkably robust, and in some children, the plural agreement appeared with a higher number of occurrences than its categorial counterpart. In Adam's and Alif's NP plural utterances, they produced quantifier + default form (e.g., five duck, three chick), with only one occurrence of quantifier + noun + suffix $-s$ each (many bottles, many apples). There is not enough evidence of formal and lexical variations for this structure in Adam's and Alif's production data; this means that they have yet to reach the NP stage at this point.

S-Procedure: The highest procedure achieved by the children is the S-Procedure which is instantiated by third-person singular structure $-s$. This stage requires feature unification at the sentence level, that is, the learners have to learn to unify the person and number features of the subject and the verb form carrying those same features (Di Biase et al, 2015). This type of agreement is called interphrasal because it occurs between two different phrases: the NP (SUBJ) and the VP. In Di Biase et al's (2015) study, their participant, Kumi, acquired this structure very late in the development. In our study, there are only 3 occurrences of third-person singular $-s$; two of which were supplied by Mimi "Sophia gives the bread" and "She gets the cookie" and one by Lily "The baby gives the bird the bread". Since Mimi has produced the morpheme in two different verbs, she satisfies the emergence criteria for the interphrasal stage. Lily shows just one occurrence of the interphrasal agreement which is insufficient evidence to ascertain that the stage has been reached. For the other children, we found that they tended to use the base form verb when producing the context for third-person singular $-s$, such as: 
1. "Sunny give the bird" (Nana)

2. "He catch it" (Adam)

3. "She go there" (Fifi)

4. "The baby hold the bread" (Rina)

5. "The baby eat the bread" (Alif)

To sum up the children's grammatical development at this point, only Mimi has reached the S-procedure stage, which is reflected in her use of third-person singular $-s$ on two verbs. Nana, Lily, Fifi, and Rina are at the Phrasal Procedure stage, which is manifested in their substantial utterances containing the $b e+V$-ing when describing ongoing actions and many NP plural quantifier + suffix $-s$ when marking plurality. Their numerous productions of these grammatical constructions strongly suggest that the emergence of the structures is remarkably robust. Adam and Alif are still at the Category Procedure level; they have yet to satisfy the emergence criterion for grammatical structures in the Phrasal stage. Figure 3 summarises the PT stage of each child.

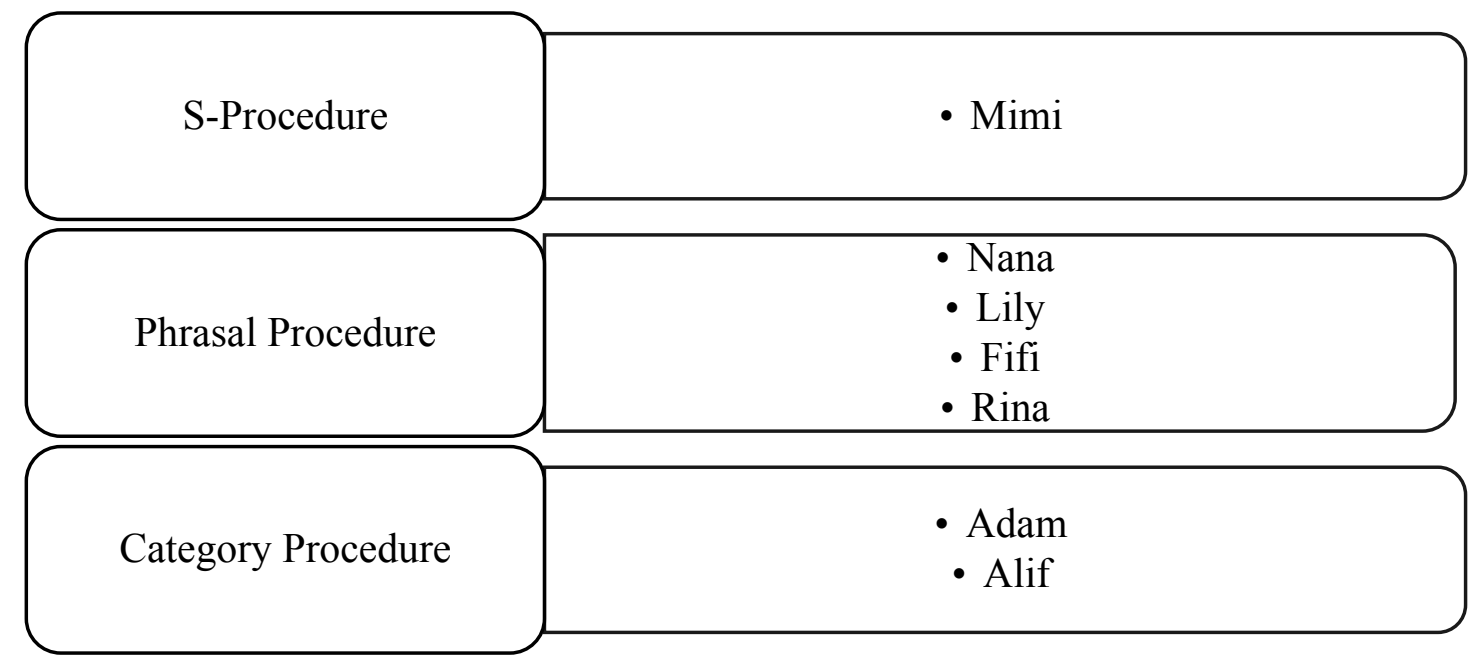

FIGURE 3. PT stage of the participants

From the findings, we can see the variation in the grammatical development between the learners. It is interesting to note that the simultaneous bilingual children in the study (Nana, Lily, Fifi, and Rina) are all in the Phrasal Procedure stage while two of the sequential bilingual children (Adam and Alif) are in the Category Procedure. Mimi, who is also a sequential bilingual child, reached the highest stage, the S-Procedure stage. If we were to solely examine the input from the home environment, we might assume that the simultaneous bilingual children, who receive higher English input at home, to be at the highest stage of grammatical development. This is not the case in the current study. Mimi's parents reported that Mimi appears to be stronger in language-related subjects (Malay, English, and Arabic); therefore, it is highly possible that language aptitude and personality characteristics are the factors underlying this outcome. In Malaysia, as English has a strong position and is well-supported in the educational system, we see that Mimi, though exposed to the language later compared to her simultaneous bilingual peers, is still able to reach the highest stage of grammatical development. 


\section{CONCLUSION}

The current study investigates the English grammatical acquisition of seven Malay-English primary school children from the Processability Theory perspective. In general, after two years in primary education, all the children have moved beyond the PT lemma stage, which means they can understand English and produce more than formulaic expressions when using the language. The differences in the grammatical acquisition between the children begin from the Category Procedure stages onwards. Two children, both sequential bilinguals, are at the PT Category Procedure stage while all the simultaneous bilinguals are at the PT Procedure stage. One child, who is a sequential bilingual, managed to reach the PT S-Procedure Stage. We postulate that the individual differences between the children stem not only from the home factors but also due to language aptitude and personal characteristics. The results of this study are important as they form the basis of understanding and establishing English developmental profiles among Malaysian children. The findings of this research may help policymakers and those responsible for curriculum design to tailor English language lessons to children's acquisition ability. Consequently, this will help young learners to better acquire the language. In addition to this, the applicability of PT across different population groups will be further supported by the findings in this study.

Some limitations of the study include the small sample size, which is typical of group case studies. The study is also further limited by the single recording session conducted on each participant. However, as mentioned earlier, this is the first of an ongoing longitudinal project investigating the children's acquisition of English lexicon and morphology. Therefore, further development regarding the children's acquisition over a longer period will be made known in future publications.

\section{ACKNOWLEDGEMENTS}

We wish to thank the insightful feedback given by the anonymous reviewers which have greatly helped improve this paper. This study is supported by IIUM Flagship Research Initiative Grant Scheme (IRF) [Project ID: IRF19-030-0030].

\section{REFERENCES}

Ali, N. L., Hamid, M. O., \& Moni, K. (2011). English in primary education in Malaysia: policies, outcomes and stakeholders' lived experiences. Current Issues in Language Planning, 12(2), 147-166. doi:10.1080/14664208.2011.584371

Artoni, D., \& Magnani, M. (2015). Acquiring case marking in Russian as a second language: an exploratory study on subject and object. In C. Bettoni \& B. Di Biase (Eds.), Grammatical Development in Second Languages: Exploring the boudaries of Processability Theory (pp. 177-194). Italy: Eurosla.

Azman, H. (2009). English in 1Malaysia: A paradox in rural pluri-literacy practices. Akademika, 76, 27-41.

Azman, H. (2016). Implementation and Challenges of English Language Education Reform in Malaysian Primary Schools. 3L: The Southeast Asian Journal of English Language Studies, 22(3), 65-78.

Berko-Gleason, J. (1958). The child's learning of English morphology. Word, 14, 150-177.

Bonilla, C. L. (2015). From number agreement to the subjunctive: Evidence for Processability Theory in L2 Spanish. Second Language Research, 31(1), 53-74. doi: $10.1177 / 0267658314537291$

Bresnan, J. (2001). Lexical-functional syntax. Oxford: Blackwell. 
Bybee, J. (1995). Regular morphology and the lexicon. Language and Cognitive Processes, $10,425-455$.

Che Musa, N., Khoo, Y. L., \& Azman, H. (2012). Exploring English Language Learning And Teaching In Malaysia. Gema Online Journal of Language Studies, 12(1), 35-51.

Clark, E. V., \& Nikitina, T. V. (2009). One vs. more than one: antecedents to plural marking in early language acquisition. Linguistics, 47(1). doi:10.1515/ling.2009.004

De Houwer, A. (2009). Bilingual first language acquisition. Bristol, UK: Multilingual Matters.

Department of Statistics Malaysia. (2017). Current population estimates, Malaysia, 2014-2017. Retrieved from https:/www.dosm.gov.my/v1/index.php? $\mathrm{r}=$ column/cthemeByCat\&cat=155\&bul $\mathrm{id}=$ OWlxdEVoYlJCS0hUZzJyRUcvZEYxZz09\&menu id=L0pheU43NWJwRWVSZk1 WdzQ4TlhUUT09

Di Biase, B., \& Bettoni, C. (2015). The development of Italian as a second language. In C. Bettoni \& B. Di Biase (Eds.), Grammatical development in second languages: exploring the boundaries of processability theory. (pp. 117-148). Italy: Eurosla.

Di Biase, B., \& Kawaguchi, S. (2002). Exploring the typological plausibility of Processability Theory: language development in Italian second language and Japanese second language. Second Language Research, 18(3), 274-302.

Di Biase, B., Kawaguchi, S., \& Yamaguchi, Y. (2015). The development of English as a second language. In Grammatical development in second languages:exploring the boundaries of processability theory (pp. 85-116). Italy: EuroSLA.

Dörnyei, Z., \& Skehan, P. (2003). Individual differences in second language learning. In C. Doughty \& M. Long (Eds.), The Handbook of Second Language Acquisition (pp. 589630). Oxford: Blackwell.

Doshi, A. (2012). Changing tides: The story of The English Language in Malaysia. In Zuraidah Mohd Don (Ed.), English in multicultural Malaysia (pp. 15-28). Kuala Lumpur: UM Press.

Fenson, L., Dale, P. S., Reznick, J. S., Bates, E., Thal, D., \& Pethick, S. (1994). Variability in early communicative development. Monographs of the society for research in child development., 59(5), 1-173.

Gao, X. (2005). Noun Phrase Morphemes and Topic DEvelopment in L2 Mandarin Chinese : A Processability Perspective. (PhD). University of Victoria, Wellington, New Zealand.

Genesee, F., \& Hamayan, E. (1980). Individual differences in second language learning. Applied Psycholinguistics, 1, 95-110.

Genesee, F., Paradis, J., \& Crago, M. (2004). Dual Language Development and Disorders: A Handbook on Bilingualism and Second Language Learning. Baltimore: Brookes.

Gentner, D., \& Boroditsky, L. (2001). Individuation, relativity, and early word learning. In M. Bowerman \& S. C. Levinson (Eds.), Language acquisition and conceptual development (pp. 215-256). Cambridge: Cambridge

Gill, S. K. (2005). Language Policy in Malaysia: Reversing Direction. Language Policy, 4(3), 241-260.

Gill, S. K. (2014). Language Policy Challenges in Multi-Ethnic Malaysia. New York: Springer.

Granena, G. (2013). Individual differences in sequence learning ability and second language acquisition in early childhood and adulthood. Language Learning, 63(4), 665-703. doi:10.1111/lang.12018

Hardini, I., Di Biase, B., Kawaguchi, S., \& Reid, C. (2020). The effect of developmentally moderated focus on form instruction in Indonesian kindergarten children learning English as a foreign language. Instructed Second Language Acquisition, 4.1, 49-61.

Hardini, I., Kawaguchi, S., Reid, C., \& Di Biase, B. (2019). Early Lexical and Grammatical Development of English in Indonesian Kindergarten Children. Asiatic, 13(1), 76-102. 
Hashim, A. (2014). English and the linguistic ecology of Malaysia. World Englishes, 33(4), 458-471.

Isai, K., Govindasamy, M., Ramalingam, R., Ching, H., \& Kausalya, M. (2020). Preparedness for the World of Work Among Malaysian Diploma Students in a Local Institution. Malaysian Journal of Social Sciences and Humanities (MJSSH), 5(4), 56-70.

Itani-Adams, Y. (2013). One child and two languages: acquisition of Japanese and English as bilingual first languages. Munchen: Lincolm.

Jackson-Maldonado, D. (2004). Verbal morphology and vocabulary in monolinguals and emergent bilinguals. In B. A. Goldstein (Ed.), Bilingual language development and disorders in Spanish-English speakers. Baltimore: Paul H. Brookes.

Jia, G., \& Fuse, A. (2007). Acquisition of English grammatical morphology by native Mandarin speaking children and adolescents: age-related differences. Journal of Speech, Language and Hearing Research, 50, 1280-1299.

Johnston, M. (1985). Syntactic and morphological progressions in learner English. Canberra: Department of Immigration and ethnic Affairs.

Johnston, M. (2000). Stages of development for English as a second language. Bankstown, NSW.: LARC/University of Western Sydney.

Kaplan, R. M., \& Bresnan, J. (1982). Lexical-functional grammar: a formal system for grammatical representation. In J. Bresnan (Ed.), The mental representation of grammatical relations (pp. 173-281). Cambridge: MIT Press.

Kawaguchi, S. (2010). Learning Japanese as a second language : a processability perspective. Amherst, NY: Cambria Press.

Kawaguchi, S. (2015). The development of Japanese as a second language. In C. Bettoni \& B. D. Biase (Eds.), Grammatical development in second languages :exploring the boundaries of processability theory. (pp. 149-172). Italy: Eurosla.

Lee, B. C., Pandian, A., Rethinasamy, S., \& Tan, D. A. I. (2019). Effects of PWIM in the ESL Classroom: Vocabulary Knowledge Development Among Primary Malaysian Learners. 3L: The Southeast Asian Journal of English Language Studies, Vol 25(4): 179 - 197(4), 179-197.

Lee, M. C. L., Krishnamoorthy, K., \& Rong, Y. J. (2019). The Role of Negotiated Interaction in L2 Vocabulary Acquisition among Primary ESL Learners. 3L: The Southeast Asian Journal of English Language Studies., 25(2), 1-21.

Leopold, W. F. (1939). Speech development of a bilingual child : a linguist's record (Vol. i: Vocabulary growth in the first two years.). Evanston, Ill: Northwestern University Press.

Levelt, W. J. M. (1989). Speaking: from intention to articulation. Cambridge: MIT Press.

Mansouri, F. (2005). Agreement morphology in Arabic as a second language: typological features and their processing implications. In M. Pienemann (Ed.), Cross-linguistic aspects of processability theory (pp. 117-153). Amsterdam: John Benjamins.

Mansouri, F., \& Håkansson, G. (2007). Conceptualising intra-stage sequencing in the learner language. In F. Mansouri (Ed.), Second language acquisition research: theoryconstruction and testing (pp. 95-119). Cambridge: Cambridge University Press.

Marchman, V., \& Bates, E. (1994). Continuity in lexical and morphological development: a test of the critical mass hypothesis. Journal of Child Language, 21, 339-366.

Marcus, G. F., Pinker, S., Ullman, M. T., Hollander, M., Rose, T. J., \& Xu, F. (1992). Overregularization in language acquisition. . Monographs of the Society for Research in Child Development, 57(4).

McLaughlin, B. (1978). Second Language Acquisition in Childhood. Hillsdale, NJ: Lawrence Erlbaum. 
Medojevic, L. (2014). The effect of the first year of schooling on bilingual language development: a study of second and third generation Serbian-Australian 5-year-old bilingual children from a processability perspective. ( $\mathrm{PhD}$ dissertation). Western Sydney University,

Meganathan, P. M., Thai, Y. N., Paramasivam, S., \& Jalaluddin, I. (2019). Incidental and Intentional Learning of Vocabulary among Young ESL Learners. 25(4), 51-67.

Meisel, J. M., Clahsen, H., \& Pienemann, M. (1981). On determining developmental stages in natural second language acquisition. Studies in Second Language Acquisition, 3, 109135.

Ministry of Education. (2013). Malaysia Education Blueprint 2013-2025 (Preschool to Post Secondary Education). Putrajaya, Malaysia: Ministry of Education Malaysia

Ministry of Education. (2015). English Language Education Reform in Malaysia: The Roadmap 2015-2025. Putrajaya: Ministry of Education Malaysia

Mohamad Uri, N. F., \& Abd Aziz, M. S. (2018). Implementation of CEFR in Malaysia: Teachers' awareness and the Challenges. 3L: The Southeast Asian Journal of English Language Studies - Vol 24(3): 168 - 183, 24(3), 168-183.

Mohamed Salleh, R. T. A. (2017). Bilingual first language acquisition in Malay and English: A morphological and suprasegmental study in the development of plural expressions in a bilingual child. (Ph.D). Western Sydney University, Australia, Retrieved from http://210.48.222.80/proxy.pac/docview/2034359984?accountid=44024

Mohamed Salleh, R. T. A., Kawaguchi, S., \& Di Biase, B. (2019). A Case Study on the Acquisition of Plurality in a Bilingual Malay-English Context-bound Child. GEMA Online ${ }^{\circledR}$ Journal of Language Studies, 19(3), 22-42.

Mohamed Salleh, R. T. A., Kawaguchi, S., Jones, C., \& Biase, B. D. (2016). The development of plural expressions in a Malay-English bilingual child. Asiatic, 10(2), 60-81.

Mohd Don, Z. (2014). English in Malaysia: An Inheritance from the Past and the Challenge for the Future. In N. Murray \& A. Scarino (Eds.), Dynamic Ecologies: A Relational Perspective on Languages Education in the Asia-Pacific Region (pp. 117-133). Dordrecht: Springer Netherlands.

Mohd Zin, Z., Eng, W. B., \& Rafik-Galea, S. (2014). Critical Reading Ability and its Relation to L2 Proficiency of Malaysian ESL Learners. 3L: The Southeast Asian Journal of English Language Studies, 20(2), 43-54.

Moyle, M. J., Weismer, S. E., Evans, J. L., \& Lindstrom, M. J. (2007). Longitudinal relationships between lexical and grammatical development in typical and late-talking children. Journal of Speech, Language, and Hearing Research, 50, 508-528.

Nicoladis, E., \& Paradis, J. (2012a). Acquiring regular and irregular past tense morphemes in English and French: evidence from bilingual children. Language Learning, 62(1), 170197.

Nicoladis, E., Song, J., \& Marentette, P. (2012b). Do young bilinguals acquire past tense morphology like monolinguals, only later? Evidence from French-English and Chinese-English bilinguals. Applied Psycholinguistics, 33(3), 457-479. doi:10.1017/S0142716411000439

Oller, K. D., \& Eilers, R. (2002). Language and Literacy in Bilingual Children. Clevendon: Multilingual Matters.

Pallotti, G. (2007). An operational definition of the emergence criterion. Applied Linguistics, 28, 361-382.

Pandian, A. (2002). English Language Teaching in Malaysia Today. Asia-Pacific Journal of Education, 22(2), 35-52. 
Paradis, J. (2007a). Early bilingual and multilingual acquisition. In P. Auer \& Li Wei (Eds.), Handbook of Multilingualism and Multilingual Communication (pp. 15-44). Berlin: Mouton De Gruyter.

Paradis, J. (2007b). Second language acquisition in childhood. In Blackwell handbook of language development. (pp. 387-405). Malden: Blackwell Publishing.

Paradis, J., Nicoladis, E., Crago, M., \& Genesee, F. (2010). Bilingual children's acquisition of the past tense: a usage-based approach. Journal of Child Language, 37, 1-25.

Pienemann, M. (1998). Language processing and second language development: processability theory. Philadelphia: John Benjamins Publishing Company.

Pienemann, M. (Ed.) (2005). Cross-linguistic aspects of processability theory. Philadelphia: John Benjamins.

Pienemann, M., \& Hakansson, G. (1999). A unified approach towards the development of Swedish as L2: Processability account. Studies in Second Language Acquisition, 21, 383-420.

Qi, R. (2011). The bilingual acquisition of English and Mandarin : Chinese children in Australia. Amherst, New York: Cambria Press.

Ranta, L. (2002). The role of learners' language analytic ability in the communicative classroom. In P. Robinson (Ed.), Individual Differences and Instructed Language Learning (pp. 159-181). Amsterdam: Benjamins.

Razak, R. A., Aziz, M. A., Lim, H. Y., \& Jin, L. (2011). Determining milestones in developmental syntax among Malay children towards the construction of a Malay syntactic assessment tool. Paper presented at the 44th Annual Meeting of the British Association for Applied Linguistics (BAAL), Bristol, UK.

Razak, R. A. (2014). Studies on the acquisition of morphology and syntax among Malay children in Malaysia: issues, challenges and needs. In H. Winskel \& P. Padakannaya (Eds.), South and Southeast Asian Psycholinguistics. Cambridge: Cambridge University Press.

Romaine, S. (1996). Bilingualism. In W. C. Ritchie \& T. K. Bhatia (Eds.), Handbook of second language acquisition (pp. 571-601). San Diego: Academic Press.

Ronjat, J. (1913). Le développement du langage observé chez un enfant bilingue. Paris: Champion.

Sabbah, M., Masood, M., \& Iranmanesh, M. (2013). Effects of graphic novels on reading comprehension in Malaysian year 5 students. Journal of Graphic Novels and Comics, 4(1), 146-160. doi:10.1080/21504857.2012.757246

Sansavini, A., Guarini, A., Alessandroni, R., Faldella, G., Giovanelli, G., \& Salvioli, G. (2006). Early relations between lexical and grammatical development in very immature Italian preterms. Journal of Child Language, 33, 199-216.

Sarudin, I., Mohd Noor, Z., Zubairi, A. M., Tunku Ahmad, T. B., \& Nordin, M. S. (2013). Needs Assessment of Workplace English and Malaysian Graduates' English Language Competency. World Applied Sciences Journal, 21, 88-94.

Sawyer, M., \& Ranta, L. (2002). Aptitude, individual differences, and instructional design. In P. Robinson (Ed.), Cognition and Second Language Instruction (pp. 319-353). Cambridge: Cambridge University Press.

Sloetjes, H., \& Wittenburg, P. (2008). ELAN (Version 4.9.3). Nijmegen, The Netherlands. Retrieved from http://tla.mpi.nl/tools/tla-tools/elan/

Sulaiman, T., Mohd. Ayub, A. F., \& Sulaiman, S. (2015). Curriculum change in English language curriculum advocates higher order thinking skills and standards-based assessments in Malaysian Primary schools. Mediterranean Journal of Social Sciences, $6(2), 494-500$. 
Ting, S.-H., Marzuki, E., Chuah, K.-M., Misieng, J., \& Jerome, J. (2017). Employers' views on the importance of english proficiency and communication skill for employability in Malaysia. Indonesian Journal of Applied Linguistics, 7(2), 315-327.

Turiman, S., Abdullah, N., \& Mohd Noor, N. (2018). Spoken Metadiscourse in Malaysian ESL Job Interviews. GEMA Online ${ }^{\circledR}$ Journal of Language Studies, 18(3).

Wilkins, D. (1972). Linguistics in Language Teaching. London: Arnold.

Wisniewski, K. (2017). Empirical learner language and the levels of the Common European Framework of Reference. . Language Learning, 67(1), 232-253.

Yamaguchi, Y. (2013). Child second language learning: A study of English as a second language acquisition. Saarbrücken, Germany: LAP Lambert Academic Publishing.

Yamat, H., Fisher, R., \& Rich, S. (2014). Revisiting English language learning among Malaysian children. Asian Social Science, 10(3), 174-180.

Yamat, H., Umar, N. F. M., \& Mahmood, M. I. (2014). Upholding the Malay language and strengthening the English language policy: an education reform. International Education Studies, 7(13), 197-205.

Yusoff, M. Y., Salehuddin, K., Abdullah, I. H., \& Toran, H. (2018). An Account of HighFunctioning Autism Spectrum Disorder (ASD) Children Focusing on Their Language Abilities. Jour of Adv Research in Dynamical \& Control Systems, 10(6), 15-22.

Yusoff, M. Y., Salehuddin, K., Abdullah, I. H., \& Toran, H. (2019). English Morphosyntactic Performance of a high-functioning ASD child: implications on ELT. Malaysian Journal of Learning and Instruction, 6(1), 155-179.

Zainuddin, S. Z., Pillai, S., Dumanig, F. P., \& Phillip, A. (2018). English language and graduate employability. Education + Training, 61(1), 79-93.

Zhang, Y. (2002). Describing the L2 acquisition process: the genitive and attributive markers of Mandarin Chinese. Journal of the Chinese Language Teachers Association, 37(2), $75-112$.

Zhang, Y. (2005). Processing and formal instruction in the L2 acquisition of five Chinese grammatical morphemes. In M. Pienemann (Ed.), Cross-linguistic aspects of processability theory. (pp. 155-177).

Zhang, Y., \& Widyastuti, I. (2010). Acquisition of L2 English morphology: a family case study. Australian review of applied linguistics, 33(3), 29.21-29.17.

\section{ABOUT THE AUTHORS}

Rabiah Tul Adawiyah Mohamed Salleh is Assistant Professor, teaching Psycholinguistics at the Department of English Language and Literature, International Islamic University Malaysia (IIUM). She is also Director of Child Bilingualism Centre, a research center under the auspices of the Kulliyyah of Islamic Revealed Knowledge and Human Sciences (KIRKHS), IIUM.

Bruno Di Biase is a supervisor of PhD students at the School of Humanities and Communication Arts and the Bilingualism Research Lab at WSU. He is an editor of the Benjamins PALART series. His research interests and publications are in Bilingualism and SLA with a focus on Processability Theory.

Wan Nur Madiha Ramlan is Assistant Professor at the Department of English Language and Literature, IIUM, where she teaches courses on American literature and Postcolonial literature. She is currently at work on projects involving Malaysian folktales and how they could be studied using Digital methods and approaches. 